\title{
Juvenile rainbow trout responses to diets containing distillers dried grain with solubles, phytase, and amino acid supplements
}

\author{
Michael E. Barnes ${ }^{1^{*}}$, Michael L. Brown ${ }^{2}$, Kurt A. Rosentrater ${ }^{3}$ \\ ${ }^{1}$ South Dakota Department of Game, Fish and Parks, McNenny State Fish Hatchery, Spearfish, USA; \\ *Corresponding Author: mike.barnes@state.sd.us \\ ${ }^{2}$ Department of Wildlife and Fisheries Sciences, South Dakota State University, Brookings, USA \\ ${ }^{3}$ Department of Agricultural and Biosystems Engineering, Iowa State University, Ames, USA
}

Received 20 December 2011; revised 19 January 2012; accepted 26 January 2012

\begin{abstract}
Distillers dried grain with solubles (DDGS) was evaluated in juvenile Shasta-strain rainbow trout Oncorhynchus mykiss diets during a 36-day feeding trial. Two experimental diets containing either $10 \%$ or $20 \%$ DDGS with supplemented amino acids (lysine, methionine, isoleucine, and histidine) and phytase were compared to a fish meal-only control diet. Tanks of trout receiving diets containing either concentration of DDGS weighed significantly less at the end of the trial and had significantly poorer feed conversion ratios than tanks of fish being fed the fish mealonly control. There was no significant difference in individual fish length, weight, condition factor, or any fish health measurements among diet treatments. Both the hepatosomatic index and viscerosomatic index were significantly less in the fish fed 10\% DDGS than those fed the control diet. Body fat was significantly greater in the fish receiving $20 \%$ DDGS compared to fish fed either of the other two diets. Fillet composition, as determined by crude protein, crude lipid, ash, and water, was not significantly different among fish reared on any of the diets. There was also no significant difference in estimated protein digestibility coefficients among fish receiving any of the diets. The results suggest that DDGS, even if supplemented with essential amino acids and phytase, will lead to decreased juvenile rainbow trout growth at dietary concentrations of at $10 \%$ or greater.
\end{abstract}

Keywords: Rainbow Trout; Oncorhynchus mykiss; DDGS; Diet; Alternative Proteins

\section{INTRODUCTION}

During hatchery rearing, rainbow trout Oncorhynchus mykiss and other carnivorous salmonids are typically fed high protein diets containing fish meal as the primary protein source [1-4]. However, because fish meal is a limited quantity, its price has increased dramatically with the rapid growth in global aquaculture [5-7]. Thus, lowercost, plant-based proteins will likely play a greater role in salmonid diets [7].

The availability of distillers dried grain with solubles (DDGS), a coproduct produced by the corn-based ethanol biofuel industry, has increased with increased ethanol production in the USA $[8,9]$. Conventional DDGS are relatively high protein, with levels approaching $30 \%$ [8, $10,11]$, and contain few, if any, of the anti-nutritional factors found in other plant protein sources [12-15]. Compared to other corn products, nutrients are more concentrated in DDGS [16], but essential amino acids such as lysine and methionine are present in lower concentrations than fish meal [4].

Philips [17] conducted the first experiments examining DDGS in rainbow trout diets, while Sinnhuber [18] documented the successful inclusion of 3\% dietary DDGS. Phillips et al. [19] used distillers dried solubles, which are similar to DDGS. At low inclusion levels in salmonid diets, other distillers grain products showed no deleterious nutritional effects [20,21]. When fed to juvenile rainbow trout, DDGS concentrations of $15 \%$ in the diet produced positive results [4], while concentrations of $22.5 \%$ were acceptable with lysine and methionine supplementation. However, all of the diets used by Cheng and Hardy [4] contained 15\% soybean meal and there was no true fish meal-only control. In a study with a fish meal control, Stone et al. [22] noted that rainbow trout receiving dietary DDGS exhibited significantly reduced growth. DDGS were also used in experimental and control diets by Cheng et al. [23] as part of a study focused 
more on the use of soybean meal and a methionine hydroxyl analogue. Lastly, Cheng and Hardy [24] also determined that phytase supplementation improved the apparent digestibility coefficients for total-phosphorous and other minerals in rainbow trout diets containing DDGS.

The inconsistent results reported with the incorporation of DDGS in rainbow trout diets, and the lack of studies comparing DDGS to an appropriate fish mealonly control, requires additional research. Thus, the objective of this study was to examine the effects of two DDGS-dietary inclusion levels, in comparison to a fish meal-only control diet, on the performance of juvenile rainbow trout during hatchery rearing.

\section{MATERIALS AND METHODS}

\subsection{Location and Fish Culture}

The trial occurred at McNenny State Fish Hatchery, Spearfish, South Dakota, USA, using degassed and aerated well water at a constant temperature of $11^{\circ} \mathrm{C}$ (total hardness as $\mathrm{CaCO}_{3}, 360 \mathrm{mg} \cdot \mathrm{L}^{-1}$; alkalinity as $\mathrm{CaCO}_{3}$, $210 \mathrm{mg} \cdot \mathrm{L}^{-1}$; $\mathrm{pH}$, 7.6; total dissolved solids, $390 \mathrm{mg} \cdot \mathrm{L}^{-1}$ ). Flow rates in each tank were set at $40 \mathrm{~L} \cdot \mathrm{min}^{-1}$. Juvenile Shasta strain rainbow trout (initial weight $33.6 \pm 1.5 \mathrm{~g}$, length $146.7 \pm 2.1 \mathrm{~mm}$, mean $\pm \mathrm{SE}$ ) were used because of availability at the time of hatchery tank space availability, and were randomly placed into each of nine fiberglass circular tanks ( $1.8 \mathrm{~m}$ diameter, $0.6 \mathrm{~m}$ depth) on September 2, 2010. Tanks were loaded with 40 fish, and total tank weights were measured to $\pm 1 \mathrm{~g}$. Feeding commenced the following day and continued for 36 days until the end of the trial. Feeding amounts for the tanks were determined by the hatchery constant $(\mathrm{HC})$ method [25], with a planned feed conversion of 1.1 and a maximum growth rate of $0.066 \mathrm{~cm} /$ day, which was based on the historical performance of the Shasta strain at McNenny State Fish Hatchery. Feed amounts were updated daily. Fish were hand fed once per day, with all feed fed and mortality data recorded daily for each tank.

\subsection{Diets and Chemical Analysis}

The nine tanks were randomly assigned to one of three different diets (Table 1), with three experiment units receiving the same diet. In addition to a fish-meal only control, two other diets contained either $10 \%$ or $20 \%$ DDGS (Poet BPX, Glenville East, South Dakota, USA). To make the essential amino acid profiles similar in all of the diets and potentially improve the acceptability of dietary DDGS [23,27], the DDGS-containing diets were supplemented with lysine, methionine, isoleucine, and histidine. In addition, phytase was added to the DDGScontaining diets to facilitate DDGS digestibility [4].
Table 1. Percent composition and chemical analysis of the diets used in the trial.

\begin{tabular}{|c|c|c|c|}
\hline \multirow{2}{*}{ Ingredients } & \multicolumn{3}{|c|}{ Diets } \\
\hline & 1 & 2 & 3 \\
\hline Fish meal, menhaden ${ }^{\mathrm{a}}$ & 40.0 & 40.0 & 30.0 \\
\hline DDGS $^{b}$ & 0.0 & 10.0 & 20.0 \\
\hline Whole wheat ${ }^{\mathrm{c}}$ & 20.0 & 13.0 & 11.0 \\
\hline Yellow corn gluten ${ }^{\mathrm{d}}$ & 25.0 & 22.0 & 22.0 \\
\hline Menhaden oil ${ }^{\mathrm{e}}$ & 11.5 & 10.8 & 10.6 \\
\hline $\mathrm{Cmc}^{\mathrm{f}}$ & 0.6 & 0.5 & 2.5 \\
\hline Vitamin premix ${ }^{g}$ & 0.5 & 0.5 & 0.5 \\
\hline Mineral premix ${ }^{\mathrm{h}}$ & 0.0 & 0.1 & 0.1 \\
\hline Vitamin C (Stay-C $)^{\mathrm{i}}$ & 0.5 & 0.5 & 0.5 \\
\hline Phytase $^{\mathrm{j}}$ & 0.0 & 0.037 & 0.037 \\
\hline Yeast $^{\mathrm{k}}$ & 0.125 & 0.125 & 0.125 \\
\hline Lysine $^{1}$ & 0.0 & 0.5 & 0.5 \\
\hline Isoleucine $^{1}$ & 0.0 & 0.3 & 0.3 \\
\hline Histidine $^{1}$ & 0.0 & 0.1 & 0.1 \\
\hline Methionine $^{1}$ & 0.0 & 0.5 & 0.5 \\
\hline Sodium chloride & 0.5 & 0.5 & 0.9 \\
\hline Potassium chloride & 0.6 & 0.6 & 0.7 \\
\hline Magnesium oxide & 0.0 & 0.0 & 0.1 \\
\hline \multicolumn{4}{|l|}{ Chemical analysis (\% dry basis $)^{\mathrm{m}}$} \\
\hline Crude protein & 45.3 & 47.1 & 44.0 \\
\hline Crude lipid & 10.7 & 11.8 & 14.3 \\
\hline Crude fiber & 1.3 & 0.9 & 1.6 \\
\hline Ash & 10.5 & 10.7 & 10.5 \\
\hline $\mathrm{DE}\left(\mathrm{MJ} \cdot \mathrm{kg}^{-1}\right.$ dry matter $)$ & 14.92 & 15.79 & 16.00 \\
\hline
\end{tabular}

${ }^{a}$ IPC 740, Scoular, Minneapolis, Minnesota, USA. ${ }^{b}$ Distillers dried grain, BPX, Poet Nutrition, Sioux Falls, South Dakota, USA. 'Bob's Red Mill Natural Foods, Milwaukie, Oregon, USA. ${ }^{\mathrm{d}}$ Consumers Supply Distributing, Sioux City, Iowa, USA. ${ }^{\mathrm{e}}$ Omega Protein, Inc., Houston, Texas, USA. ${ }^{\mathrm{f}}$ Carboxymethyl cellulose, USB Corporation, Cleveland, Ohio, USA. ${ }^{\mathrm{g}} \mathrm{ARS} 702$, [26], Nelson and Sons, Inc., Murray, Utah, USA. ${ }^{\mathrm{h}}$ ARS 640, [26], Nelson and Sons, Inc., Murray, Utah, USA. 'DSM Nutritional Products France SAS, Village-Neuf, France. ${ }^{j}$ Ronozyme P-CT, DSM Nutritional Products, Basel, Switzerland. ' Diamond V, Cedar Rapids, Iowa, USA. 'PureBulk, Roseburg, Oregon, USA. ${ }^{\mathrm{m}}$ Analysis conducted on post-extrusion pellets.

Pelleted diets were produced by extrusion processing. Experimental diets were analyzed according to AOAC [28] methodology for protein (method 2001.11) and crude lipid (method 2003.5, modified by substituting petroleum ether for diethyl ether), and ash content by AACC [29] method 08 - 03. The protein and lipid amounts obtained by these methods were multiplied by their respective physiological fuel values of 23.6 and $39.5 \mathrm{~mJ}$ [3] to obtain estimated digestible energy values.

\subsection{Data Collection}

At the end of the trial, total tank weights were meas- 
ured to $\pm 1 \mathrm{~g}$, with weight gain calculated by subtracting the initial weight from the final weight for each tank. Percent (relative) gain was calculated by dividing the total amount of food fed by the initial tank weight. Feed conversion ratio for each tank was calculated by dividing the total amount of food fed by the total weight gain. In addition to total tank measurements, five fish from each tank were randomly selected from each tank, euthanized and individually weighed to $\pm 1 \mathrm{~g}$ and measured (total length) to $\pm 1 \mathrm{~mm}$. Fish health profiles, based on a modification of Goede and Barton [30], Adams et al. [31], and Barton et al. [32], were completed using the score sheet described in Table 2. Liver weights were recorded to \pm 1 $\mathrm{mg}$ and the hepatosomatic index (HSI) determined by dividing the liver weight [g] by whole fish weight [g] and multiplying by 100 [33]. Viscera weights were also recorded to the nearest $\mathrm{mg}$ and the viscerosomatic index (VSI) determined by dividing the viscera weight [g] by the whole fish weight [g] and multiplying by 100 . Condition factor was calculated as $\mathrm{K}=10^{5} \times$ (weight [g])/ (length $\left.{ }^{3}[\mathrm{~mm}]\right)$.

Table 2. Criteria used at the end of the study for fish health observations (based on Goede and Barton [30], Adams et al. [31], and Barton et al. [32]).

\begin{tabular}{|c|c|c|}
\hline Structure or Tissues & Rating Criteria & Numeric Rating \\
\hline \multirow{2}{*}{ Eyes } & Normal & 0 \\
\hline & Abnormal & 1 \\
\hline \multirow{4}{*}{ Fat } & None & 0 \\
\hline & $<50 \%$ of gut covered & 1 \\
\hline & $>50 \%$ of gut covered & 2 \\
\hline & $100 \%$ of gut covered & 3 \\
\hline \multirow{4}{*}{ Fins } & No erosion & 0 \\
\hline & Light erosion & 1 \\
\hline & Moderate erosion & 2 \\
\hline & Severe erosion & 3 \\
\hline \multirow{2}{*}{ Gills } & Normal & 0 \\
\hline & Clubbed, frayed, or discolored & 1 \\
\hline \multirow{4}{*}{ Gut } & Normal & 0 \\
\hline & Slight inflammation & 1 \\
\hline & Moderate inflammation & 2 \\
\hline & Severe inflammation & 3 \\
\hline \multirow{2}{*}{ Kidney } & Normal & 0 \\
\hline & Abnormal & 1 \\
\hline \multirow{2}{*}{ Liver } & Normal & 0 \\
\hline & Abnormal & 1 \\
\hline \multirow{2}{*}{ Pseudobranchs } & Normal & 0 \\
\hline & Abnormal & 1 \\
\hline \multirow{2}{*}{ Opercles } & Normal & 0 \\
\hline & Short & 1 \\
\hline \multirow{2}{*}{ Spleen } & Normal & 0 \\
\hline & Cysts or enlarged & 1 \\
\hline
\end{tabular}

\subsection{Protein Digestability}

Apparent protein digestability was determined using a direct method [34]. Digesta was removed from five fish per tank at the end of the trial. Each fish was dissected and the last $\mathrm{cm}$ of the distal end of the intestine was gently squeezed to remove the contents. Digesta from five fish per tank was pooled and flash frozen on dry ice prior to analysis. Protein analysis was conducted using AOAC [28] method 990.03. Percent apparent protein digestability was calculated by subtracting the protein in the digesta from the protein in the diet, dividing this quantity by the protein in the diet, and multiplying by 100 .

\subsection{Fillet Composition}

Muscle fillets were removed and flash frozen for determination of carcass composition. The fillets from each tank were pooled and analyzed for crude protein levels with a TruSpec CNS combustion analyzer (LECO Corp., St. Joseph, Michigan, USA) using AOAC [28] method 992.15. AOAC [28] acid hydrolysis method 948.15 with a 50:50 mix of diethyl ether and petroleum ether for extraction was used for fat analysis. Moisture was determined by drying loss using AOAC [28] method 952.08.

\subsection{Statistical Analysis of Data}

Data were analyzed using the SPSS (9.0) statistical analysis program (SPSS, Chicago, Illinois, USA) with significance predetermined at $\mathrm{P}<0.05$. One-way analysis of variance (ANOVA) was conducted, and if the treatments were significantly different, pairwise mean comparisons were performed using the Tukey HSD test [35]. Mortality (\%) data were arcsine transformed prior to analysis to stabilize the variances [35].

\section{RESULTS}

Tanks of trout receiving diets containing either concentration of DDGS weighed significantly less at the end of the trial than those tanks of fish being fed the fish meal-only control (Table 3). Total tank weight gain was $1011 \mathrm{~g}$ in the control tanks, and only $962 \mathrm{~g}$ and $940 \mathrm{~g}$ in the tanks receiving diets with $10 \%$ DDGS or $20 \%$ DDGS, respectively. Relative gain was not significantly different among the diets $(\mathrm{P}=0.07)$. Feed conversion ratio among the diets followed a similar pattern, at 0.82 in the fish meal-only control tanks, which was significantly different from the $10 \%$ DDGS tanks at 0.87 and the tanks receiving the $20 \%$ DDGS diet at 0.89 . At $94 \%$, the apparent digestion coefficient of protein in the tanks receiving $20 \%$ dietary DDGS was significantly different from either of the other two diets.

Individual fish lengths, weights, and condition factors were not significantly different among the diets tested 
(Table 4). However, viscera weight and the viscera somatic index (VSI) were significantly lower in the fish fed

Table 3. Total tank rearing data (means $\pm \mathrm{SE}$ ), including feed conversion ratio and estimated digestion coefficient of protein (DCP) for tanks of rainbow trout receiving one of three different diets containing either $0 \%$ (control), $10 \%$ or $20 \%$ Distillers Dried Grains with Solubles (DDGS) and phytase. Means in a row with different letters are significantly different $(\mathrm{N}=3, \mathrm{P}<$ $0.05)$.

\begin{tabular}{cccc}
\hline Diet & 1 & 2 & 3 \\
\% DDGS & 0 & 10 & 20 \\
\hline Start Weight (g) & $1218 \pm 45$ & $1252 \pm 59$ & $1261 \pm 24$ \\
End Weight (g) & $2229 \pm 44$ & $2214 \pm 42$ & $2201 \pm 14$ \\
Gain (g) & $1011 \pm 10^{\mathrm{a}}$ & $962 \pm 9^{\mathrm{b}}$ & $940 \pm 7^{\mathrm{b}}$ \\
Gain (\%) & $83.2 \pm 3.2$ & $77.0 \pm 1.6$ & $74.6 \pm 1.1$ \\
Food fed (g) & 834 & 834 & 834 \\
FCR & $0.82 \pm 0.01^{\mathrm{a}}$ & $0.87 \pm 0.01^{\mathrm{b}}$ & $0.89 \pm 0.01^{\mathrm{b}}$ \\
\% mortality & $0.0 \pm 0.0$ & $0.0 \pm 0.0$ & $0.0 \pm 0.0$ \\
DCP & $91.4 \pm 0.1^{\mathrm{a}}$ & $90.8 \pm 0.1^{\mathrm{a}}$ & $94.0 \pm 0.1^{\mathrm{b}}$ \\
\hline
\end{tabular}

Table 4. Ending mean ( \pm SE) lengths, weights, condition factors $(\mathrm{K})^{\mathrm{a}}$, liver weights, hepatosomatic index values (HSI) ${ }^{\mathrm{b}}$, viscera weights, viscerosomatic index (VSI)c and fish health assessmentsd of rainbow trout fed diets containing either $10 \%$ or $20 \%$ Distillers Dried Grains with Solubles (DDGS) and phytase ( $\mathrm{N}=$ $3)$. Means in the same row with different letters are significantly different $(\mathrm{P}<0.05)$.

\begin{tabular}{lccc}
\hline \multicolumn{1}{c}{ Diet } & 1 & 2 & 3 \\
\multicolumn{1}{c}{$\%$ DDGS } & 0 & 10 & 20 \\
\hline Length (mm) & $179 \pm 3$ & $165 \pm 5$ & $174 \pm 2$ \\
Weight (g) & $59.6 \pm 3.6$ & $49.4 \pm 3.1$ & $57.0 \pm 1.9$ \\
K & $1.00 \pm 0.01$ & $1.02 \pm 0.03$ & $1.03 \pm 0.01$ \\
Viscera weight (g) & $6.12 \pm 0.36^{\mathrm{a}}$ & $4.52 \pm 0.26^{\mathrm{b}}$ & $5.64 \pm 0.08^{\mathrm{ab}}$ \\
VSI & $10.32 \pm 0.24^{\mathrm{a}}$ & $8.99 \pm 0.24^{\mathrm{b}}$ & $9.89 \pm 0.19^{\mathrm{ab}}$ \\
Liver weight $(\mathrm{g})$ & $0.73 \pm 0.01^{\mathrm{a}}$ & $0.51 \pm 0.02^{\mathrm{b}}$ & $0.62 \pm 0.02^{\mathrm{c}}$ \\
HSI & $1.26 \pm 0.06^{\mathrm{a}}$ & $1.01 \pm 0.04^{\mathrm{b}}$ & $1.09 \pm 0.01^{\mathrm{ab}}$ \\
Eyes & $0.0 \pm 0.0$ & $0.0 \pm 0.0$ & $0.0 \pm 0.0$ \\
Fat & $1.6 \pm 0.1^{\mathrm{a}}$ & $1.6 \pm 0.1^{\mathrm{a}}$ & $1.9 \pm 0.1^{\mathrm{b}}$ \\
Fins & $1.2 \pm 0.2$ & $1.4 \pm 0.1$ & $1.1 \pm 0.1$ \\
Gills & $0.3 \pm 0.1$ & $0.5 \pm 0.1$ & $0.3 \pm 0.1$ \\
Gut & $0.0 \pm 0.0$ & $0.0 \pm 0.0$ & $0.0 \pm 0.0$ \\
Kidney & $0.0 \pm 0.0$ & $0.0 \pm 0.0$ & $0.0 \pm 0.0$ \\
Liver & $0.0 \pm 0.0$ & $0.0 \pm 0.0$ & $0.0 \pm 0.0$ \\
Pseudobranchs & $0.0 \pm 0.0$ & $0.0 \pm 0.0$ & $0.0 \pm 0.0$ \\
Opercles & $0.2 \pm 0.1$ & $0.3 \pm 0.1$ & $0.1 \pm 0.1$ \\
Spleen & $0.0 \pm 0.0$ & $0.0 \pm 0.0$ & $0.0 \pm 0.0$ \\
\hline Con & $10^{5} \times($ igh &
\end{tabular}

${ }^{a}$ Condition factor $(\mathrm{K})=10^{5} \times($ weight $) /\left(\right.$ length $\left.{ }^{3}\right) ;{ }^{b}$ Hepatosomatic index $(\mathrm{HSI})$ $=100 \times($ liver weight $/$ body weight $) ;{ }^{\mathrm{C}}$ Viscerosomatic index $(\mathrm{VSI})=100 \times$ (viscera weight/body weight); ${ }^{\mathrm{d}}$ Fish health assessments rating system described in Table 2. the $10 \%$ DDGS than in the fish receiving the control diet. There was no significant difference in either viscera weight or VSI between the fish receiving 20\% DDGS compared to fish receiving either of the other two diets. The hepatosomatic index (HSI) followed a similar pattern as viscera weight and VSI. Liver weight was significantly different among all of the diets. With a mean ranking of 1.9 , body fat was significantly greater in the fish receiving 20\% DDGS compared to fish fed either of the other two diets with mean rankings of 1.6. There were no significant differences for any of the other fish health or condition parameters evaluated.

There were no significant differences in fillet composition in fish receiving any of the three diets (Table 5). Mean fillet protein levels ranged from 18.6 from the trout receiving the fish meal-only control diet to 19.5 in the fish fed the $10 \%$ DDGS-diet. Variation in crude lipid levels was observed from the fish receiving either of the diets containing DDGS.

\section{DISCUSSION}

The decreased gain and feed conversion ratio observed in any of the tanks receiving either of the diets containing DDGS in this study differs from the conclusions of Cheng and Hardy [4] that incorporation of $15 \%$ DDGS, or $22.5 \%$ DDGS with methionine and lysine supplementation, is acceptable in rainbow trout diets. Cheng and Hardy [4] did not compare their DDGS-containing diets to a fish meal-only control however; experimental and control diets in that study also contained $15 \%$ soybean meal as a protein source. Stone et al. [22] also found decreased growth in rainbow trout receiving DDGS compared to a fish meal control. Further comparison of this study to Cheng and Hardy [4] reveals that they manufactured their diets via cold-pelleting, versus twinscrew extrusion in this study, which may contribute to the differing results [36-38]. The difference in the water temperature used between the two studies, $11^{\circ} \mathrm{C}$ in the present study versus $14.5^{\circ} \mathrm{C}$ by Cheng and Hardy [4], may have had some effect [39-41]. The often dramatic differences in conventional DDGS nutritional composition $[8,42,43]$ also make it difficult to compare the re-

Table 5. Mean $( \pm \mathrm{SE})$ percent composition of fillets of rainbow trout fed diets containing either $10 \%$ or $20 \%$ Distillers Dried Grains with Soluble (DDGS) with phytase (N=3).

\begin{tabular}{cccc}
\hline Diet & 1 & 2 & 3 \\
\% DDGS & 0 & 10 & 20 \\
\hline Water (\%) & $77.3 \pm 0.9$ & $77.0 \pm 0.1$ & $75.9 \pm 0.3$ \\
Crude protein (\%) & $18.6 \pm 0.3$ & $19.5 \pm 0.2$ & $19.2 \pm 0.2$ \\
Crude lipid (\%) & $4.6 \pm 0.1$ & $3.6 \pm 0.2$ & $4.0 \pm 0.3$ \\
Ash (\%) & $1.5 \pm 0.1$ & $1.4 \pm 0.1$ & $1.5 \pm 0.1$ \\
\hline
\end{tabular}


sults between studies examining DDGS use in rainbow trout diets.

The 10\% DDGS diet used in this study had the same amount of fish meal and slightly higher protein levels than the control diet, yet still produced significantly poorer trout growth. The difference in growth could be due to some unidentified anti-nutritional factors [12-15] present in the DDGS. Because the diets also differed in the amount of wheat and corn gluten, it is also possible that these ingredients may have influenced the results.

Although Cheng and Hardy [24] recommend the inclusion of phytase in rainbow trout diets containing DDGS, the inclusion of phytase in the experimental diets of this study did not lead to similar rearing performance as the fish meal-only control diet. Phytase supplementation had no effect on growth or feed conversion in the rainbow trout fed diets containing 15\% DDGS [24]. Although the results of phytase supplementation in diets incorporating soy products on rainbow trout growth are mixed [44-48], it generally has had no effect on growth or feed conversion ratio when fed to other fish species [49-52], with the exception of common carp Cyprinus carpio [53] and Nile tilapia Oreochromis niloticus [54]. Phytase does increase the availability of phosphorous in fish feeds containing plant ingredients [55-59], but the diets in the current study were supplemented with a dietary phosphate, likely preventing any plant-related phosphorus deficiency. The efficiency of phytase may be somewhat dependent on the method used to incorporate it into the feed [51], making it possible that the phytase might have been partially inactivated during extrusion processing in this study [60]. Phytase activity was not measured in this study however.

Protein digestibility was significantly increased in the fish receiving 20\% DDGS feed. The 94\% estimated digestibility was greater than that observed by Cheng and Hardy [24]. These relatively high protein digestibilities could be because of the high protein digestibility of DDGS itself [24] or in combination with the amino acid supplementation in the experimental diets [61-64].

Unlike the studies by Lim et al. [65] and Li et al. [66], fillet lipid concentrations did not increase with increasing DDGS levels. Rather, the results from this study were similar to those of Johnsen et al. [67], who observed no difference in Atlantic salmon Salmo salar muscle fat concentrations fed diets containing a wide range of plant protein inclusion rates. Fillet protein levels also did not decrease with the addition of DDGS to the diet, in contrast to Li et al. [66] and Li et al. [68]. The percent moisture and crude protein of fillets from the rainbow trout receiving the control, fish meal-only diet were very similar to that reported by Yildiz [69], but less than that reported by Sealey et al. [70]. However, the rainbow trout fillets analyzed by Sealey et al. [70] came from fish that were fed a $29 \%$ fish meal control diet that also contained $16 \%$ soybean meal.

Although the hepatosomatic index is positively related to carbohydrate levels in the diet $[71,72]$, HSI was only increased in the fish receiving 10\% DDGS in this study. Other diet studies examining HSI have produced inconsistent results. For example, HSI either slightly decreased, or showed no effect, due to dietary DDGS in tilapia [73, 74], and was also unaffected by dietary protein in common carp [75]. Because dietary phosphorus is inversely related to liver lipid levels and HSI, [76], phytase supplementation may explain some of the variation in results.

The VSI followed a similar pattern as HSI, with only the $10 \%$ DDGS diets producing significantly decreased levels. It was expected that VSI would have been elevated in the fish receiving $20 \%$ DDGS because of the greater dietary lipid levels [77-79], but that was not the case with the results from this study. However, visual estimates of fat were significantly greater in the fish fed $20 \%$ DDGS, which could indicate either that not all of the visceral fat was removed during weighing of the viscera, or that the visual estimation technique is unreliable.

The relatively low feed conversion ratios for both the control and reference diet are not unusual for production rainbow trout at this size at hatcheries in South Dakota [80] or elsewhere [81]. The low feed conversion ratios could also possibly be explained by the low rearing densities used in the trial $[82,83]$.

Although specific feeding trial durations are not universally specified, they generally need to last long enough for any potential significant differences among the diets to materialize [84]. In a study by de Francesco et al. [85], differences in trout rearing performance between fish meal and plant-based diets did not become apparent until after 12 weeks. This study lasted only 36 days, but this was long enough for significant differences in gain and feed conversion ratio to appear among the diets. While possible, it is unlikely that prolonging this trial for a longer period would have led different results.

Lastly, although the DDGS-containing diets did lead to significantly decreased growth, the replacement of fish meal with DDGS in the $20 \%$ DDGS diets do produce a positive economic benefit. Based on the most current United States Department of Agriculture Economic Research Service Data from October 2011 [86], with the price of DDGS and fish meal at US $\$ 0.233 / \mathrm{kg}$ and $\$ 1.158 / \mathrm{kg}$ respectively, the cost per $\mathrm{kg}$ of fish flesh gained for the fish meal component of the control diet would be $\$ 0.565$, compared to $\$ 0.443$ for the fish meal and DDGS component of the $20 \%$ DDGS diet. Thus, substituting DDGS for a portion of the fish meal is a viable option if decreases in growth and feed efficiency can be tolerated. 


\section{CONCLUSION}

The results of this study indicate that, given the ingredients used, the inclusion of $10 \%$ or greater amounts of DDGS in the diet of juvenile Shasta-strain rainbow trout will lead to decreased growth and feed conversion, but still may be economically advantageous. It is unknown if these results would be similar for other trout strains or species reared at different water temperatures and different projected growth rates. The effect of dietary DDGS on different sizes of trout is also uncertain.

\section{ACKNOWLEDGEMENTS}

The authors thank the Agriculture Experiment Station, South Dakota State University, South Dakota Department of Game, Fish and Parks, and the North Central Agricultural Research Laboratory, USDA-ARS, Brookings, South Dakota, for funding, facilities, equipment, and supplies. Furthermore, the assistance of Nancy Barnes, Parisa Fallahi, Eric Krebs, Kamal Mjoun, Rilie Morgan, Patrick Nero, Sharon Nichols, Jill Tycz, Mehmet Tulbek, and Sarah Zimmerman is greatly appreciated. This study was conducted under South Dakota State University Institutional Animal Care and Use Committee (IACUC) number 08-030A.

\section{REFERENCES}

[1] Satia, B.P. (1974) Quantitative protein requirements of rainbow trout. Progressive Fish-Culturist, 36, 80-85. doi:10.1577/1548-8659(1974)36[80:QPRORT]2.0.CO;2

[2] Kim, K.I., Kayes, T.B. and Amundson, C.H. (1991) Purified diet development and reevaluation of the dietary protein requirement of fingerling rainbow trout. (Oncorhynchus mykiss). Aquaculture, 96, 57-67. doi:10.1016/0044-8486(91)90139-X

[3] National Research Council (NRC) (1993) Nutrient requirements of fish. National Academy Press, Washington DC.

[4] Cheng, Z.J. and Hardy, R.W. (2004) Nutritional value of diets containing distiller's dried grain with solubles for rainbow trout, Oncorhynchus mykiss. Journal of Applied Aquaculture, 15, 101-113. doi:10.1300/J028v15n03 08

[5] Tacon, A.G.J. and Metian, M. (2008) Global overview of the use of fish meal and fish oil in industrially compounded aquafeeds: Trends and future prospects. Aquaculture, 285, 146-158. doi:10.1016/j.aquaculture.2008.08.015

[6] Food and Agricultural Organization of the United Nations [FAO] (2009) The state of the world fisheries and aquaculture. Food and Agriculture Organization, Rome. http://www.fao.org/docrep/011/i0250e/i0250e00.HTM

[7] Hardy, R.W. (2010) Utilization of plant proteins in fish diets: Effects of global demand and supplies of fishmeal. Aquaculture Research, 41, 770-776. doi:10.1111/j.1365-2109.2009.02349.x

[8] Rosentrater, K.A. and Muthukumarappan, K. (2006) Corn ethanol coproducts: Generation properties, and future prospects. International Sugar Journal, 108, 648-657.
[9] Renewable Fuels Association (RFA) (2011) Biorefinery locations.

http://www.ethanolrfa.org/bio-refinery-locations

[10] Wu, Y.V., Rosati, R.R. and Brown, P.B. (1997) Use of corn-derived ethanol products and synthetic lysine and tryptophan for growth of tilapia (Oreochromis niloticus) fry. Journal of Agricultural and Food Chemistry, 45, 2174-2177. doi:10.1021/jf960880u

[11] Spiehs, M.J., Whitney, M.H. and Shurson, G.C. (2002) Nutrient database for distiller's dried grains with solubles produced from new ethanol plants in Minnesota and South Dakota. Journal of Animal Science, 80, 2639-2645.

[12] Jauncey, K. and Ross, B. (1982) A guide to tilapia feeds and feeding. Institute of Aquaculture, University of Stirling, Stirling.

[13] Wilson, R.P. and Poe, W.E. (1985) Effects of feeding soybean meal with varying trypsin inhibitor activities on growth of fingerling channel catfish. Aquaculture, 46, 1925. doi:10.1016/0044-8486(85)90171-1

[14] Shiau, S.Y., Chuang, J.L. and Sun, G.L. (1987) Inclusion of soybean meal in tilapia (Oreochromis niloticus $\times O$. aureus) diets at two protein levels. Aquaculture, 65, 251261. doi:10.1016/0044-8486(87)90238-9

[15] Robinson, E.H. (1991) Improvement of cottonseed meal protein with supplemental lysine in feeds for channel catfish. Journal of Applied Aquaculture, 1, 1-14. doi:10.1300/J028v01n02 01

[16] Chevanan, N., Rosentrater, K.A. and Muthukumarappan, K. (2008) Effect of DDGS, moisture content, and screw speed on the physical properties of extrudates in single screw extrusion. Cereal Chemistry, 85, 132-139. doi:10.1094/CCHEM-85-2-0132

[17] Phillips, A.M. (1949) Fisheries Research Bulletin No. 13. Cortland Hatchery Reports No. 18, Cortland, New York.

[18] Sinnhuber, R.O. (1964) Pelleted fish food. Feedstuffs, 36, 16.

[19] Phillips, A.M., Hammer, G.L., Edwards, J.P. and Hosking, H.F. (1964) Dry concentrates as complete trout foods for growth and egg production. Progressive Fish-Culturist, 26, $155-159$. doi:10.1577/1548-8640(1964)26[155:DCACTF]2.0.CO;2

[20] Fowler, L.G. and Banks, J.L. (1976) Fish meal and wheat germ substitutes in the Abernathy diet. Progressive FishCulturist, 38, 127-130. doi:10.1577/1548-8659(1976)38[127:FMAWGM]2.0.CO ;2

[21] Hughes, S.G. (1987) Distillers products in salmonid diets. Proceedings of the Distillers Feed Conferences, 4, 27-31.

[22] Stone, D.A., Hardy, R.W., Barrows, F.T. and Cheng, Z.J. (2005) Effects of extrusion on nutritional value of diets containing corn gluten meal and corn distiller's dried grain for rainbow trout Oncorhynchus mykiss. Journal of Applied Aquaculture, 17, 1-20. doi:10.1300/J028v17n03 01

[23] Cheng, Z.J., Hardy, R.W. and Blair, M. (2003) Effects of supplementing methionine hydroxyl analogue in soybean meal and distillers dried grain-based diets on the performance and nutrient retention of rainbow trout $[\mathrm{On}$ - 
corhynchus mykiss (Walbaum)]. Aquaculture Research, 34, 1303-1310. doi:10.1046/j.1365-2109.2003.00940.x

[24] Cheng, Z.J. and Hardy, R.W. (2004) Effect of microbial phytase supplementation in corn distiller's dried grain with solubles on nutrient digestibility and growth performance of rainbow trout, Oncorhynchus mykiss. Journal of Applied Aquaculture, 15, 83-100.

doi:10.1300/J028v15n03 07

[25] Buterbaugh, G.L. and Willoughby, H. (1967). A feeding guide for brook, brown and rainbow trout. Progressive Fish-Culturist, 29, 210-215. doi:10.1577/1548-8640(1967)29[210:AFGFBB]2.0.CO;2

[26] Cheng, Z.J., Hardy, R.W. and Usry, J.L. (2003) Effects of lysine supplementation in plant protein-based diets on the performance of rainbow trout (Oncorhynchus mykiss) and apparent digestibility coefficients of nutrients. Aquaculture, 215, 255-265. doi:10.1016/S0044-8486(02)00166-7

[27] Barrows, F.T., Gaylord, T.G., Sealey, W.M., Porter, L. and Smith, C.E. (2008) The effect of vitamin premix in extruded plant-based and fish-meal based diets on growth efficiency and health of rainbow trout, Oncorhynchus mykiss. Aquaculture, 283, 148-155.

doi:10.1016/j.aquaculture.2008.07.014

[28] Association of Official Analytical Chemists (AOAC) (2009) Official Methods of for Analysis, (online version). http://www.eoma.aoac.org/

[29] American Association of Cereal Chemists (AACC) (2000) Approved methods of the American Association of Cereal Chemists. 10th Edition, AACC, St. Paul.

[30] Goede, R.W. and Barton, B.A. (1990) Organismic indices and an autopsy-based assessment as indicators of health and condition in fish. In: Adam, S.M., Ed., Biological Indicators of Stress in Fish, American Fisheries Society, Bethesda, 93-108.

[31] Adams, S.M., Brown, A.M. and Goede, R.W. (1993) A quantitative health assessment index for rapid evaluation of fish condition in the field. Transactions of the American Fisheries Society, 122, 63-73.

doi:10.1577/1548-8659(1993)122<0063:AQHAIF >2.3.C $\underline{\mathrm{O} ; 2}$

[32] Barton, B.A., Morgan, J.D. and Vijayan, M.M. (2002) Physiological and condition-related indicators of environmental stress in fish. In: Adams, S.M., Ed., Biological Indicators of Aquatic Ecosystem Stress, American Fisheries Society, Bethesda, 111-148.

[33] Strange, R.J. (1996) Field examination of fishes. In: Murphy, B.R. and Willis D.W., Eds., Fisheries Techniques, 2nd Edition, American Fisheries Society, Bethesda, 433-466.

[34] Windell, J.T., Foltz, J.W. and Sarokon, J.A. (1978) Method of faecal collection and nutrient leaching in digestibility studies. Progressive Fish-Culturist, 40, 51-55. doi:10.1577/1548-8659(1978)40[51:MOFCAN]2.0.CO;2

[35] Kuehl, R.O. (2000) Design of experiments: Statistical principles of research design and analysis. 2nd Edition, Brookes/Cole, Pacific Grove.

[36] Jeong, K.S., Takeuchi, T. and Watanabe, T. (1991) Improvement of nutritional quality of carbohydrate ingredi- ents by extrusion processes in diets of red seabream. Nippon Suisan Gakkaishi, 57, 1543-1549. doi: $10.2331 /$ suisan. 57.1543

[37] Cheng, Z.J. and Hardy, R.W. (2003) Effects of extrusion processing of feed ingredients on apparent digestibility coefficients of nutrients for rainbow trout (Oncorhynchus mykiss). Aquaculture Nutrition, 9, 77-83. doi:10.1046/j.1365-2095.2003.00226.x

[38] Glencross, B., Hawkins, W., Evans, D., Rutherford, N., McCafferty, P., Dods, K. and Hauler, R. (2011) A comparison of the effect of diet extrusion or screw-press pelleting on the digestibility of grain protein products when fed to rainbow trout (Oncorhynchus mykiss). Aquaculture, 312, 154-161. doi:10.1016/j.aquaculture.2010.12.025

[39] Watanabe, T., Takeuchi, T., Satoh, S. and Kiron, V. (1996) Digestible crude protein contents of various feedstuffs determined with four freshwater species. Fisheries Science, 62, 278-282.

[40] Watanabe, T., Takeuchi, T., Satoh, S. and Kiron, V. (1996) Methodological influences and mode of calculation. Fisheries Science, 62, 288-292.

[41] Azevedo, P.A., Cho, C.Y., Leeson, S. and Bureau, D.P. (1998) Effects of feeding level and water temperature on growth, nutrient and energy utilization and waste outputs of rainbow trout (Oncorhynchus mykiss). Aquatic Living Resources, 11, 227-238. doi:10.1016/S0990-7440(98)89005-0

[42] Belyea, R.L., Eckhoff, S.R., Wallig, M.A. and Tumbleson, M.E. (1998) Variability in the nutritional quality of distillers solubles. Bioresource Technology, 66, 207-212. doi:10.1016/S0960-8524(98)00062-5

[43] Abo-State, H.A., Tahoun, A.M. and Hammouda, Y.A. (2009) Effect of replacement of soybean by DDGS combined with commercial phytase on Nile tilapia (Oreochromis niloticus) fingerlings growth performance and feed utilization. American-Eurasian Journal of Agriculture and Environmental Science, 5, 473-479.

[44] Lanari, D., D’Agaro, E. and Turri, C. (1998) Use of nonlinear regression to evaluate the effects of phytase enzyme treatment of plant protein diets for rainbow trout (Oncorhynchus mykiss). Aquaculture, 161, 345-356. doi:10.1016/S0044-8486(97)00282-2

[45] Vielma, J., Lall, S.P., Koskela, J., Schoner, F.J. and Mattila, P. (1998) Effects of dietary phytase and cholecalciferol on the trace element metabolism by rainbow trout (Oncorhynchus mykiss). Aquaculture, 163, 309-323. doi:10.1016/S0044-8486(98)00240-3

[46] Forster, I., Higgs, D.A., Dosanjh, B.S., Rowshandeli, M. and Parr, J. (1999) Potential for dietary phytase to improve the nutritive value of canola protein concentrate and decrease phosphorous output in rainbow trout (Oncorhynchus mykiss) held in $11^{\circ} \mathrm{C}$ fresh water. Aquaculture, 179, 109-125. doi:10.1016/S0044-8486(99)00156-8

[47] Vielma, J., Mäkinen, T., Ekholm, P. and Koskela, J. (2000) Influence of dietary soy and phytase levels on performance and body composition of large rainbow trout (Oncorhynchus mykiss) and algal availability of phosphorous load. Aquaculture, 183, 349-362. 


\section{doi:10.1016/S0044-8486(99)00299-9}

[48] Dalsgaard, J., Ekmann, K.S., Pedersen, P.B. and Verlhac, V. (2009) Effect of supplemented fungal phytase on performance and phosphorus availability by phosphorus-depleted juvenile rainbow trout (Oncorhynchus mykiss), and on the magnitude and composition of phosphorus waste output. Aquaculture, 286, 105-112. doi:10.1016/j.aquaculture.2008.09.007

[49] Sajjadi, M. and Carter, C.G. (2004) Dietary phytase supplementation and the utilization of phosphorus by Atlantic salmon (Salmo salar L.) fed a canola-meal-based diet. Aquaculture, 240, 417-431. doi:10.1016/j.aquaculture.2004.07.003

[50] Yoo, G.-Y., Wang, X., Choi, S., Han, K., Kang, J.-C. and Bai, S.C. (2005) Dietary microbial phytase increased the phosphorous digestibility in juvenile Korean rockfish Sebaste schlegeli fed diets containing soybean meal. Aquaculture, 243, 315-322.

doi:10.1016/j.aquaculture.2004.10.025

[51] Denstadli, V., Storebakken, T., Svihus, B. and Skrede, A. (2007) A comparison of online phytase pre-treatment of vegetable feed ingredients and phytase coating in diets for Atlantic salmon (Salmo salar L.) reared in cold water. Aquaculture, 269, 414-426. doi:10.1016/j.aquaculture.2007.02.033

[52] Lim, S.-J. and Lee, K.-J. (2009) Partial replacement of fish meal by cottonseed meal and soybean meal with iron and phytase supplementation for parrot fish Oplegnathus fasciatus. Aquaculture, 290, 283-289. doi:10.1016/j.aquaculture.2009.02.018

[53] Nwanna, R.E., Eisenreich, R. and Schwarz, F.J. (2007) Effect of wet-incubation of dietary plant feedstuffs with phytases on growth and mineral digestibility by common carp (Cyprinus carpio L). Aquaculture, 271, 461-468. doi:10.1016/j.aquaculture.2007.04.020

[54] Liebert, F. and Portz, L. (2005) Nutrient utilization and Nile tilapia Oreochromis niloticus fed plant based low phosphorus diets supplemented with graded levels of different sources of microbial phytase. Aquaculture, 248, 111-119. doi:10.1016/j.aquaculture.2005.04.009

[55] Cain, K.D. and Garling, D.L. (1995) Pre-treatment of soybean meal with phytase for salmonids diets to reduce phosphorus concentrations in hatchery effluents. Progressive Fish-Culturist, 57, 114-119.

doi:10.1577/1548-8640(1995)057<0114:POSMWP $>2.3$. $\mathrm{CO} ; 2$

[56] Jackson, L.S., Li, M.H. and Robinson, E.H. (1996) Use of microbial phytase in channel catfish Ictalurus punctatus diets to improve utilization of phytate phosphorus. Journal of the World Aquaculture Society, 27, 309-313. doi:10.1111/j.1749-7345.1996.tb00613.x

[57] Li, M.H. and Robinson, E.H. (1997) Microbial phytase can replace inorganic phosphorus supplements in channel catfish Ictalurus punctatus diets. Journal of the World Aquaculture Society, 28, 402-406. doi:10.1111/j.1749-7345.1997.tb00287.x

[58] Rodehutscord, M. and Pfeffer, E. (1995) Effects of supplemental microbial phytase on phosphorus digestibility and utilization in rainbow trout (Oncorhynchus mykiss). Water Science and Technology, 31, 143-147. doi:10.1016/0273-1223(95)00433-N

[59] Sugiura, S.H., Gabaudan, J., Dong, F.M. and Hardy, R.W. (2001) Dietary microbial phytase supplementation and the utilization of phosphorus, trace minerals and protein by rainbow trout [Oncorhynchus mykiss (Walbaum)] fed soybean meal-based diets. Aquaculture Research, 32, 583592. doi:10.1046/j.1365-2109.2001.00581.X

[60] Cao, L., Wang, W., Yang, C., Yang, Y., Diana, J., Yakupitiyage, A., Luo, Z. and Li, D. (2007) Application of microbial phytase in fish feed. Enzyme and Microbial Technology, 40, 497-507.

doi:10.1016/j.enzmictec.2007.01.007

[61] Krogdahl, A., Lea, T.B. and Olli, J.J. (1993) Soybean proteinase inhibitors affect intestinal trypsin activities and amino acid digestibilities in rainbow trout (Oncorhynchus mykiss). Comparative Biochemistry and Physiology Part A: Physiology, 107, 215-219. doi:10.1016/0300-9629(94)90296-8

[62] Pongmaneerat, J., Watanabe, T., Takeuchi, T. and Satoh, S. (1993) Use of different protein meals as partial or total substitution for fish meal in carp diets. Nippon Suisan Gakkaishi, 59, 1249-1257. doi:10.2331/suisan.59.1249

[63] Rodehutscord, M., Becker, A., Pack, M. and Pfeffer, E. (1997) Response of the rainbow trout (Oncorhynchus mykiss) to supplements of individual essential amino acids in a semipurified diet, including an estimate of the maintenance requirement for essential amino acids. $\mathrm{Nu}$ trition, 127, 1166-1175.

[64] Yamamoto, T., Sugita, T. and Furuita, H. (2005) Essential amino acid supplementation to fish meal-based diets with low protein to energy ratios improves the protein utilization in juvenile rainbow trout Oncorhynchus mykiss. Aquaculture, 246, 379-391. doi:10.1016/j.aquaculture.2005.02.013

[65] Lim, C., Yildririm-Aksoy, M. and Klesius, P.H. (2009) Growth response and resistance to Edwarsiella ictaluri of channel catfish, Ictalurus punctatus, fed diets containing distiller's dried grains with solubles. Journal of the World Aquaculture Society, 40, 182-193. doi:10.1111/j.1749-7345.2009.00241.x

[66] Li., M.H., Robinson, E.H., Oberle, D.F. and Lucas, P.M. (2010) Effects of various corn distillers by-products on growth, feed efficiency, and body composition of channel catfish, Ictalurus punctatus. Aquaculture Nutrition, 16, 188-193. doi:10.1111/j.1365-2095.2009.00650.x

[67] Johnsen, C.A., Hagen, Ø. and Bendiksen, E.Á. (2011) Long-term effects of high-energy, low-fishmeal feeds on growth and flesh characteristics of Atlantic salmon (Salmo salar L.). Aquaculture, 312, 109-116. doi:10.1016/j.aquaculture.2010.12.012

[68] Li, M.H., Oberle, D.F. and Lucas, P.M. (2011) Evaluation of corn distillers dried grains with solubles and brewers yeast in diets for channel catfish Ictalurus punctatus (Rafinesque). Aquaculture Research, 42, 1424-1430. doi:10.1111/j.1365-2109.2010.02734.x

[69] Yildiz, M. (2004) The study of fillet quality and the growth performance of rainbow trout (Oncorhynchus my- 
kiss) fed with diets containing different amounts of vitamin E. Turkish Journal of Fisheries and Aquatic Sciences, 4, 81-86.

[70] Sealey, W.M., Gaylord, T.G., Barrows, F.T., Tomberlin, J.K., McGuire, M.A., Ross, C. and St.-Hilaire, S. (2011) Sensory analysis of rainbow trout, Oncorhynchus mykiss, fed enriched black soldier fly prepupae, Hermetia illucens. Journal of the World Aquaculture Society, 42, 34-45. doi:10.1111/j.1749-7345.2010.00441.x

[71] Daniels, W.H. and Robinson, E.H. (1986) Protein and energy requirements of juvenile red drum (Sciaenops ocellatus). Aquaculture, 53, 243-252. doi:10.1016/0044-8486(86)90354-6

[72] Kim, J.D. and Kaushik, S.J. (1992) Contributions of digestible energy from carbohydrates and estimation of protein/energy requirements for growth of rainbow trout (Oncorhynchus mykiss). Aquaculture, 106, 161-169. doi:10.1016/0044-8486(92)90200-5

[73] Schaeffer, T.W., Brown, M.L. and Rosentrater, K.A. (2009) Performance characteristics of Nile tilapia (Oreochromis niloticus) fed diets containing graded levels of fuel-based distillers dried grains with solubles. Journal of Aquaculture Feed Science and Nutrition, 1, 78-83. doi:10.3923/joafsnu.2009.78.83

[74] Schaeffer, T.W., Brown, M.L., Rosentrater, K.A. and Muthukumarappan, K. (2010) Utilization of diets containing graded levels of ethanol production co-products by Nile tilapia. Journal of Animal Physiology and Animal Nutrition, 94, 348-354. doi:10.1111/j.1439-0396.2010.01020.x

[75] Fine, M., Zilberg, D., Cohen, Z., Degani, G., Moav, B. and Gertler, A. (1996) The effect of dietary protein level, water temperature and growth hormone administration on growth and metabolism in the common carp (Cyprinus carpio). Comparative Biochemistry and Physiology, 114A, 35-42. doi:10.1016/0300-9629(95)02085-3

[76] Sakamota, S. and Yone, Y. (1978) Effect of dietary phosphorus level on chemical composition of red sea bream. Bulletin of the Japanese Society of Scientific Fisheries, 44, 227-229. doi:10.2331/suisan.44.227

[77] Jobling, M., Koskela, J. and Savolainen, R. (1998) Influence of dietary fat level and increased adiposity on growth and fat deposition in rainbow trout, Oncorhynchus mykiss (Walbaum). Aquaculture Research, 29, 601-607. doi:10.1111/j.1365-2109.1998.tb01174.x
[78] Company, R., Calduch-Giner, J.A., Kaushik, S., and Perez-Sanchez, J. (1999) Growth performance and adiposity in gilthead sea bream (Sparus aurata): Risks and benefits of high energy diets. Aquaculture, 171, 279-292. doi:10.1016/S0044-8486(98)00495-5

[79] Yildiz, M., Sener, E. and Timur, M. (2006) Effect of seasonal change and different commercial feeds on proximate composition of sea bream (Sparus aurata). Turkish Journal of Fisheries and Aquatic Sciences, 6, 99-104.

[80] Barnes, M.E., Wintersteen, K., Krebs, E., Nero, P., Tycz, J., Reichert, S. and Zimmerman, S. (2011) 2010 McNenny State fish hatchery annual production report. South Dakota Department of Game, Fish and Parks Annual Report 11-03, Pierre.

[81] Figueiredo-Silva, A.C., Rema, P., Bandarra, N.M., Nunes, M.L. and Valente, L.M.P. (2005) Effects of dietary conjugated linoleic acid on growth, nutrient utilization, body composition, and hepatic lipogenesis in rainbow trout juveniles (Oncorhynchus mykiss). Aquaculture, 248, 163172. doi:10.1016/j.aquaculture.2005.04.022

[82] Holm, J.C., Refstie, T. and BØ, S. (1990) The effect of fish density and feeding regimes on individual growth rate and mortality in rainbow trout (Oncorhynchus mykiss). Aquaculture, 89, 252-232. doi:10.1016/0044-8486(90)90128-A

[83] Procarione, L.S., Barry, T.P. and Malison, J.A. (1999) Effects of high rearing densities and loading rates on the growth and stress responses of juvenile rainbow trout. North American Journal of Aquaculture, 61, 91-96. doi:10.1577/1548-8454(1999)061<0091:EOHRDA>2.0. $\mathrm{CO} ; 2$

[84] Weatherup, R.N. and McCraken, K.J. (1999) Changes in rainbow trout, Oncorhynchus mykiss (Walbaum), body composition with weight. Aquaculture Research, 30, 305-307. doi:10.1046/j.1365-2109.1999.00320.x

[85] De Francesco, M., Parisi, G., Médale, F., Lupi, P., Kaushik, S.J. and Poli, B.M. (2004) Effect of long-term feeding with a plant protein mixture based diet on growth and body/fillet quality traits of large rainbow trout (Oncorhynchus mykiss). Aquaculture, 236, 413-429. doi:10.1016/j.aquaculture.2004.01.006

[86] United States Department of Agriculture Economic Research Service (2011). NEW feed grains data: Yearbook tables (online). http://www.ers.usda.gov/data/feedgrains/Table.asp?t=16 